\title{
Employment Growth in St. Louis
}

\author{
by R. ALTON GILBERT
}

N RECENT years the St. Louis economy has not expanded as rapidly as that of the nation. ${ }^{1}$ The trend rate of employment growth during the last seventeen years has been slower in St. Louis, and this slower rate of growth has been especially pronounced since 1966. Payroll employment in St. Louis declined throughout the period from 1969 to 1972 and has begun to increase only in recent months.

The purposes of this article are to measure the extent to which employment growth in St. Louis has differed from the national rate, to determine the influence of individual industrial sectors on the deviation of St. Louis employment from the national trend, and to compare the employment growth in St. Louis with that of some other metropolitan areas of similar size. No attempts are made to either explain the performance of the St. Louis economy, or test hypotheses about urban economic growth.

\section{THE ST: LOUTS STTUATION}

As shown in Table I, the period since 1966 is the longest in the last seventeen years during which the growth rate of payroll employment was higher each year in the nation than in St. Louis. The annual rates of growth in payroll employment for St. Louis and the nation were 1.6 and 2.1 percent, respectively, from 1955 to 1966 , and 0.4 and 2.2 percent, respectively, from 1966 to 1972 . These divergent growth rates suggest that the period between 1966 and 1972 is of special interest in an analysis of trends in the $\mathrm{St}$. Louis economy.

The term "St. Louis" is used to indicate the St. Louis SMSA as defined through 1972, which includes: St. Louis City and St. Louis, St. Charles, Jefferson, and Franklin Counties in. Missouri, and Madison and St. Clair Counties in Illinois.

zData on total nonagricultural payroll employment in St. Louis are available only as far back as the mid-1950s.

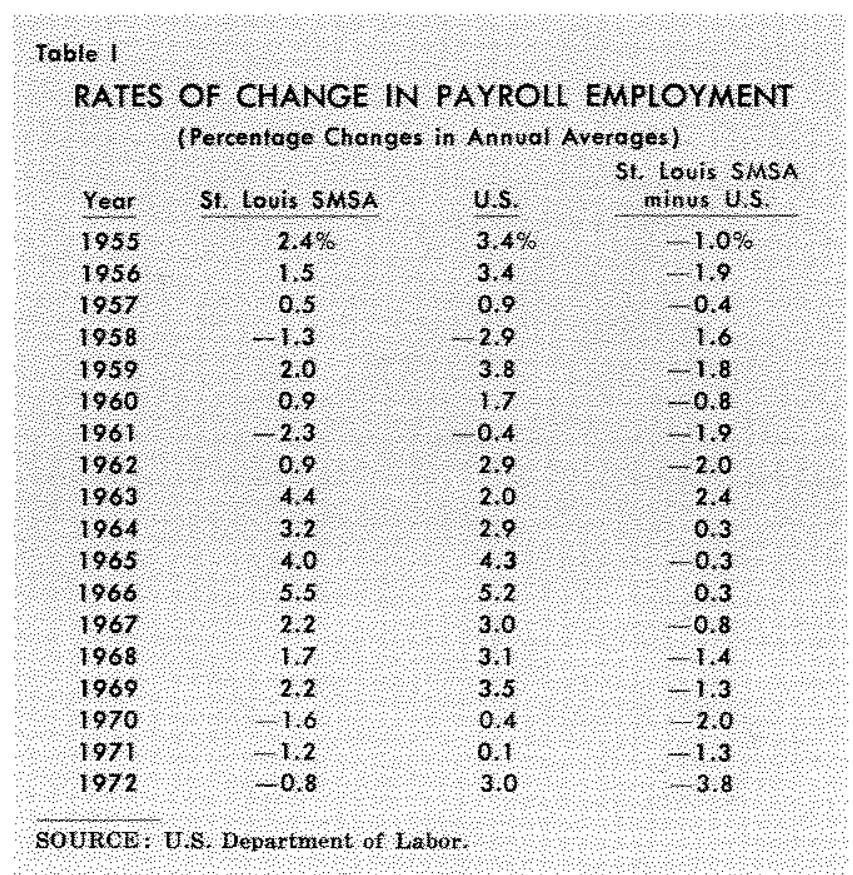

\section{Measumg the Deviation from the Natonal Trend}

The industrial composition of employment in any region is generally different from that in the nation as a whole because of the advantages of specialization. In one geographic region employment may be concentrated in sectors that experience slow growth nationally, and in another it may be concentrated in fast growing sectors. The difference between the rate of employment growth in a region and the nation may thus reflect two influences:

(1) differences in the industrial composition of employment and

(2) differences in the rates of employment growth in the region and the nation for individual industrial sectors. 
Table 11

PAYROL EMPLOYMENT IN THE ST. IOUIS SMSA BY INDUSTRIAL SECTOR

Nonseasonolly AdUsted Annual heroges, in Thousondst

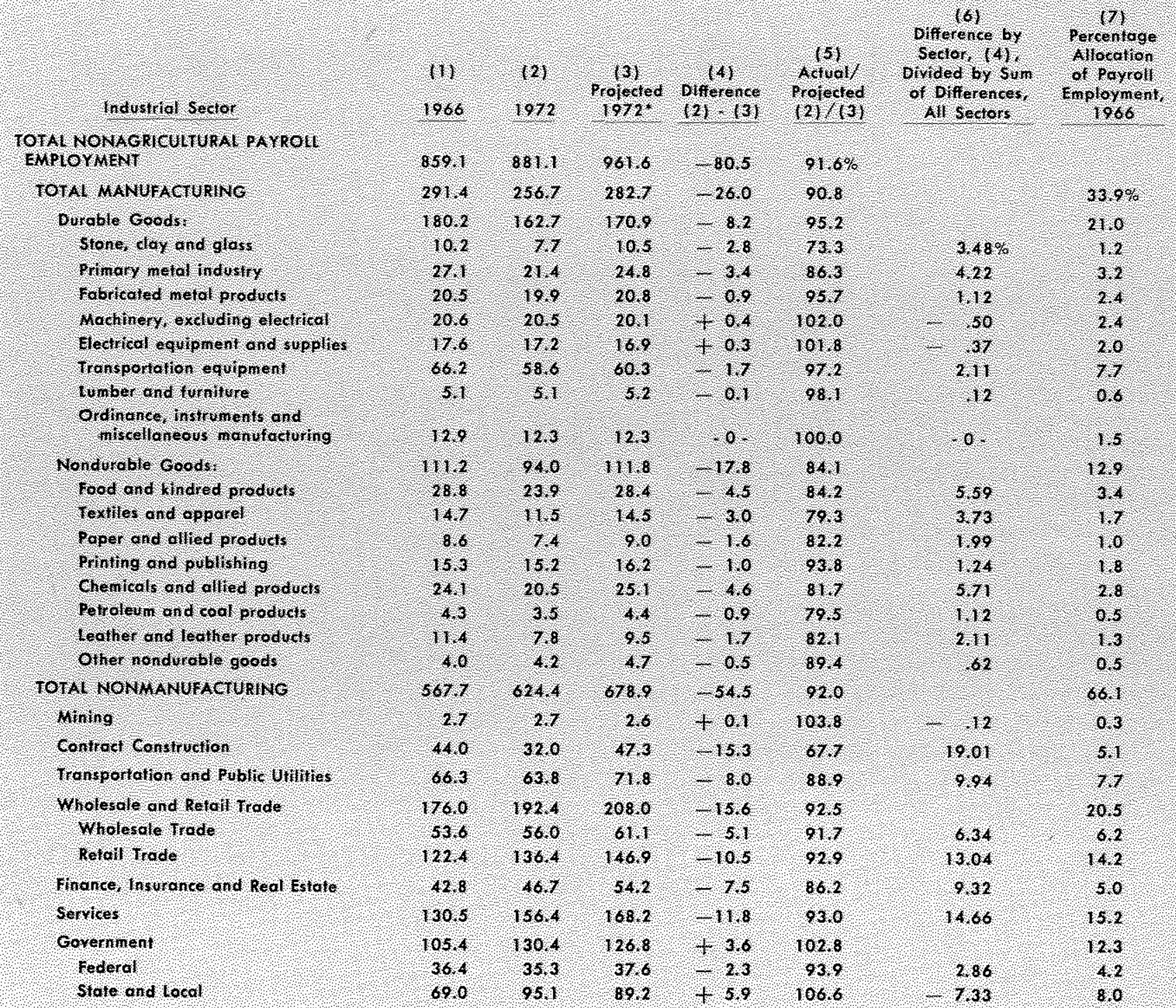

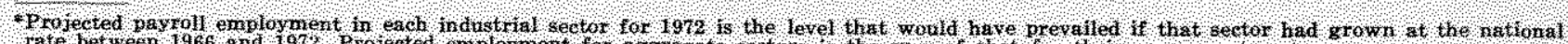

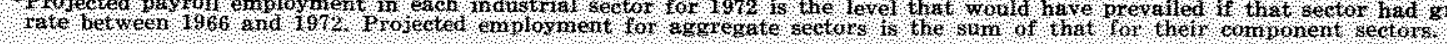
SOURon, Ut: S, Department of $\mathrm{G}$ bor

The difference between employment growth in St. Louis and the nation is measured by holding the influence of industrial composition constant. This procedure involves (1) calculating for each industrial sector the difference between actual employment in St. Loutis for 1972 and projected employment, assuming the national rate of employment growth for that sector between 1.966 and 1972 , and (2) summing the difference between actual and projected employment over all industrial sectors. The deviation of actual from projected employment shows the extent to which the slower rate of employment growth in St. Louis was the result of a slower than national growth rate in the individual sectors. ${ }^{3}$

The difference between actual and projected payroll employment in St. Louis is calculated in Table II. Column (3) gives the level that payroll employment

${ }^{3}$ For a discussion of the use of this technique in measuring regional economic growth, see Harvey $\mathrm{S}$, Perloft et al, Regions, Resources, and Economic Growth (Baltimore: The Johns Hopkins Press, 1960), and Hugh O. Nourse, Regional Economics (New York: McGraw Hill Co., 1968), pp, 192-97. 
would have been in each industrial sector in 1972 if the sector had grown at the national rate. ${ }^{4}$ The difference between actual and projected employment is presented in column (4).

Actual minus projected payroll employment for all industrial sectors in 1972 is a negative 80,500 . In other words, 80,500 more people would have been reported on payroll employment in St. Louis if employment in each industrial sector had grown at the national rate during the previous six years. This difference represents about 9 percent of current payroll employment in St. Louis.

The industrial composition of employment in St. Louis was also a factor in the area's slower rate of employment growth. Total payroll employment in the nation increased 16.1 percent between 1966 and 1972 . In contrast, projected payroll employment in St. Louis for 1972, based on national growth rates in individual sectors, was only 11.9 percent higher than actual in 1966. An implication of this comparison is that employment in St. Louis during 1966 was concentrated in industrial sectors that have had relatively slow growth throughout the nation in recent years.

\section{Performance in Individual Industral Sectors}

In column (5) of Table II, actual payroll employ. ment in St. Louis in 1972 is calculated as a percent of projected employment for each sector. The lowest ratio in column (5) is for contract construction, in which actual payroll employment for 1972 was only about 68 percent of what it would have been had it grown at the national rate. Other industrial sectors in which actual employment was especially low relative to projected employment are: (a) stone, clay, and glass, (b) textiles and apparel, and (c) petroleum and coal products. Sectors in which St. Louis payroll employment grew faster than the national rate are: (a) machinery, excluding electrical, (b) electrical

Note that projected 1972 payroll employment for aggregate industrial sectors, such as durable goods, equals the sum of the projections for each industrial sector in those categories. Projected payroll employment for such aggregate sectors, and for total payroll employment, would possibly be different if based upon the national rate of growth in those aggregate sectors because of the differences between St. Louis and the nation in industrial composition. To illustrate, projected 1972 employment in the durable goods sector would be 173,900 if that projection were calculated by multiplying $S t$. Louis employment in durable goods production in 1966 by the ratio of durable goods manufacturing in the nation in 1972 to that in 1966. The level of durable goods employment obtained by aggregating the projections for the individual sectors is 170,900 . This indicates that in 1966 the durable goods payroll employment in St. Louis was concentrated in sectors that have had relatively slow growth at the national level. equipment and supplies, (c) mining, and (d) government.

The ratios of actual to projected employment in column (5) do not give a complete picture of the influence on the St. Louis economy of employment growth in individual sectors. They do not reflect the shares of St. Louis employment involved in each sector which is also important. To illustrate, employment in a particular sector could have grown very slowly in St. Louis relative to the national rate and still have had little influence on the local economy if only a small share of local employment had been involved in that sector. The total influence of individual sectors on the performance of the St. Louis economy can be measured by dividing the difference between actual and projected employment in each sector by the difference between actual and projected employment for all sectors combined. These percentages shown in column (6) give the share of the difference between local and national employment growth of 80,500 accounted for by each sector.

About 72 percent of the difference between actual and projected employment is accounted for by nonmanufacturing activities. These activities comprised about 66 percent of total payroll employment in 1966 [see column (7)]. Contract construction accounted for 19 percent of the total difference, but that sector accounted for only about 5 percent of payroll employment in 1966. The services sector accounted for 15 percent of the overall difference, retail trade 13 percent, and the nondurable goods manufacturing sector about 22 percent. The only sector in which payroll employment in St. Louis grew at a significantly faster rate than in the nation was state and local govermment. State and local government employment was 5,900 higher in 1972 than it would have been if that sector had grown only at the national rate [see column (4)].

\section{COMPARTONS WITH OTHER CITIES}

Without specifying what influences have caused the slow employment growth in St. Louis, it may be possible to identify some employment growth patterns which are common to large metropolitan areas. For example, if employment also has grown slowly in the same individual sectors of other metropolitan areas of comparable size, we could conclude that growth in those sectors tends to be inhibited in large metropoli$\tan$ areas. Employment growth in St. Louis is compared to that in the following large metropolitan areas: Baltimore, Boston, Cleveland, Detroit, Pittsburgh, and San Francisco. On the basis of total pay. 
roll employment in 1972, three of these areas rank just above St. Louis and three just below. ${ }^{5}$

Detailed analysis of payroll employment in these areas is presented in the Appendix. The years chosen for comparison are 1964 and 1972 , covering a period during which the geographic bounds of these metro politan areas have remained unchanged." The accompanying chart of employment in the seven SMSAs indicates that there were no unusual deviations from their trends in 1964 or 1972. Thus, employment growth rates within this period should be representative of growth rates in recent years. The degree to which payroll employment data are disaggregated by industrial sectors varies from one area to another and, therefore, the disaggregation in the Appendix that is common to all seven areas is less detailed than that in Table II. Both Table II and the Appendix are constructed such that columns with the same heading number involve the same calculation.

\section{Overall Deviations from the National Trend}

The differences between actual and projected employment in column (4) of the Appendix are added for each SMSA to give a measure of the extent to which employment growth in each of the seven areas deviated from the national trend between 1964 and 1972. These results, which assume uniform industrial composition among the SMSAs and the nation, are summarized in Table III on the following page. Column (1) of Table III presents the overall deviation from the national trend for the seven metropolitan areas as calculated in column (4) of the Appendix.

Payroll employment in each of the seven metropolitan areas would have been higher in 1972 if employment in each industrial sector listed in the Appendix had grown at the national rates for those sectors during the previous eight years. The deviation from the national trend was lowest in Baltimore where projected employment exceeded the actual count by 18,200 people and highest in Boston where the projected exceeded the actual by 114,300 people.

5Washington, D. C. is of comparable size to St. Louis but is not included in the analysis because of its large percentage of employment in the government sector, which does not reflect market forces.

tThe Cleveland SMSA was increased in 1964 by adding Geanga and Medina Counties.

This measure of deviation from the national trend is different for St. Louis in Tables II and III because different years and different degrees of disaggregation are used in these two tables.

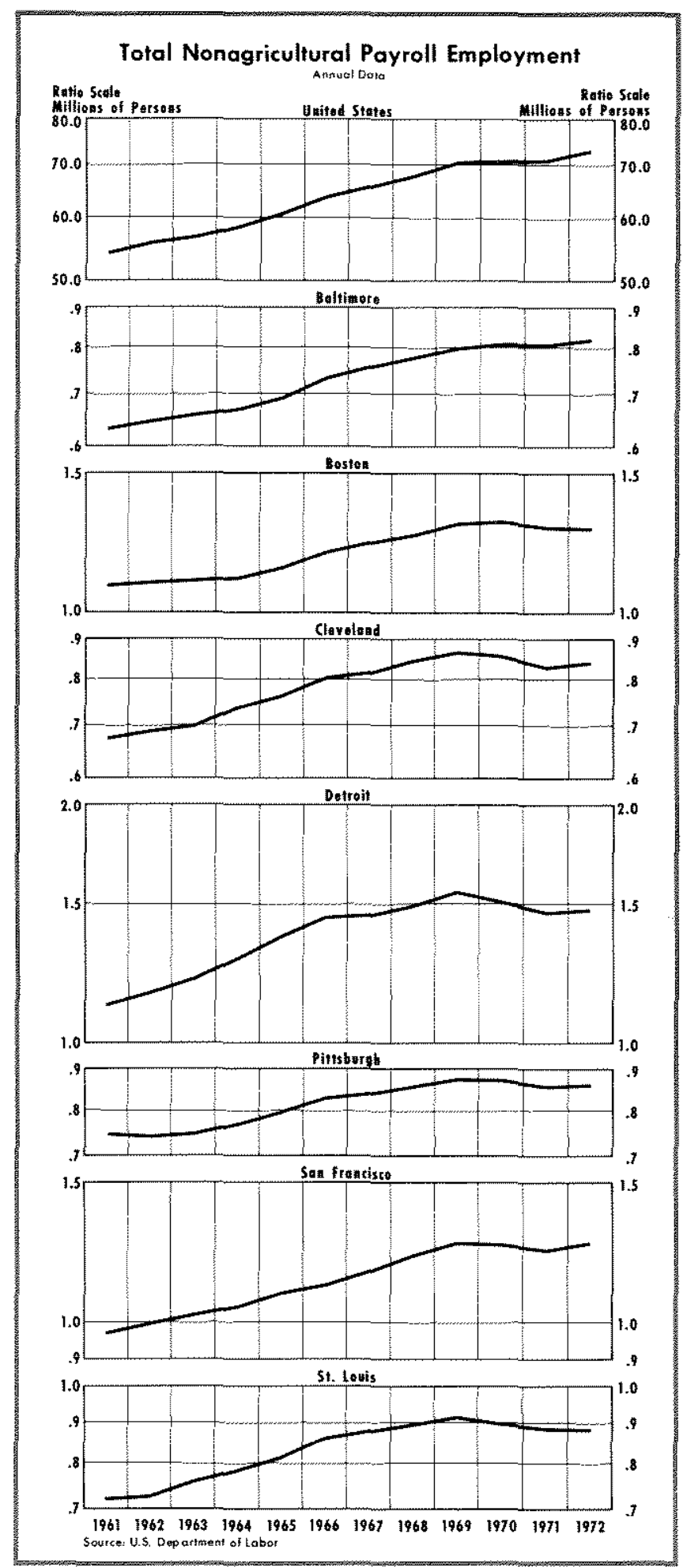

To rank these areas on the basis of how well their employment has kept pace with the nation, the overall deviation of employment growth from the national trend [column (1) of Table III] is calculated as a percentage of actual payroll employment, as shown in column (3). Baltimore had the best rela- 


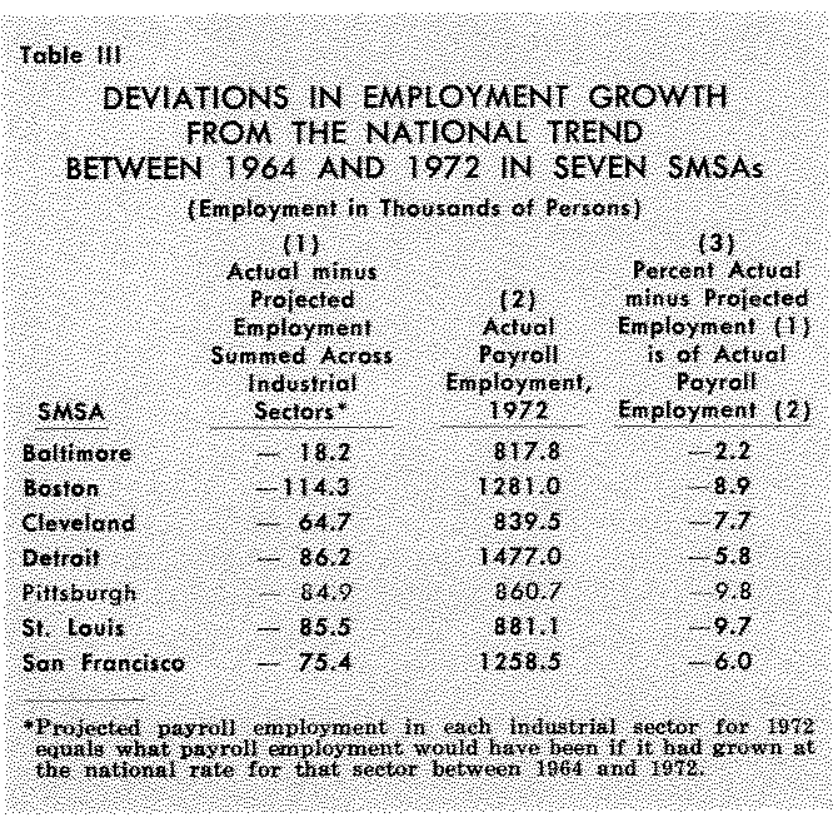

tive performance. Payroll employment there would have been only 2.2 percent higher in 1972 if each sector had grown at the national rate. Pittsburgh's 9.8 percent represented the highest percentage deviation, followed closely by St. Louis with a deviation of 9.7 percent. Only in Boston and Pittsburgh were the percentage deviations comparable to that of St. Louis.

\section{Changes in the Industrial Composition of Payroll Employment in Large SMSAs}

The industrial composition of employment in the seven metropolitan areas changed systematically between 1964 and 1972. All had large reductions in the percentage of payroll employment engaged in manufacturing, and such reductions were more pronounced than in the nation. The shares of total payroll employment involved in contract construction declined in all seven areas except Pittsburgh. All had increases in the shares of employment in wholesale and retail trade, finance, insurance and real estate, and services. Employment in the services sector in Baltimore, Boston, and San Francisco increased faster than the national rate for that sector. The percentage of employment in the government sector increased in all seven SMSAs except Boston, where it remained essentially unchanged. Government employment in Baltimore,
Detroit, and St. Louis increased faster than the national rate for that sector. In summary, during recent years employment in these large metropolitan areas of comparable size to St. Louis has been shifting out of manufacturing and contract construction and into wholesale and retail trade, finance, insurance and real estate, services, and government employment.

\section{CONCUSIONS}

On average, employment in St. Louis has grown at a slower rate than that in the nation since at least the mid-1950s, and the difference between local and national growth has increased since 1966. If employment in each industrial sector in St. Louis had grown at the national rate for that sector between 1966 and 1972 , payroll employment would have been 80,500 higher, or about 9 percent greater, than it actually was in 1972 .

The growth of local employment relative to the nation varied widely among individual industrial sectors. A sharp decline in contract construction activity accounted for 19 percent of the deviation of employment growth in St. Louis from the national trend. Other industrial sectors that accounted for large shares of this difference are services and retail trade. Sectors in which employment rose faster in St. Louis than in the nation are machinery, electrical equipment and supplies, mining, and government.

Rates of employment growth in St. Louis and six other large metropolitan areas are compared to the national rate of employment growth between 1964 and 1972 to determine whether slow employment growth has been typical of large metropolitan areas. In all seven areas, payroll employment grew less rapidly than in the nation as a whole, holding constant the influence of industrial composition. The deviation of employment growth from the national trend in St. Louis was similar to that in Boston and Pittsburgh, but larger than the deviations in the other four large metropolitan areas.

Changes in the industrial composition of St. Louis employment during recent years were similar to those in the six other areas. Employment in manufacturing decreased more rapidly in these large metropolitan areas than in the nation, and their shares of employment in wholesale and retail trade, finance, services, and govermment generally increased.

Appendix follows on pages 14-15. 


\section{APPENDIX}

PAYROLL EMPLOYMENT IN SEVEN SMSAS BY INDUSTRIAL SECTOR

(Nonseasonally Adịusted Annual Averages, itt Thousands)

\begin{tabular}{|c|c|c|c|c|c|c|c|c|}
\hline Industrial Sector & 1964 & 1972 & $\begin{array}{c}\text { Projected } \\
1972^{*}\end{array}$ & $\begin{array}{l}\text { Difference } \\
(2)-(3)\end{array}$ & $\begin{array}{c}\text { Actual/Projected } \\
(2) /(3)\end{array}$ & $\begin{array}{c}(6) \\
\text { Difference by } \\
\text { Sector, (4). } \\
\text { Divided by Sum } \\
\text { of Differences, } \\
\text { All Sectors }\end{array}$ & $\begin{array}{c}(7) \\
\text { Percentage } \\
\text { Allocation } \\
\text { of Payroll } \\
\text { Employment. } \\
1964 \\
\end{array}$ & $\begin{array}{c}\text { (8) } \\
\text { Percenfoge } \\
\text { Allocalion } \\
\text { of Payroll } \\
\text { Employment, } \\
1972\end{array}$ \\
\hline \multicolumn{9}{|c|}{ BALTIMORE } \\
\hline TOIAL. NONAGRICUITURAL PAYROLL EMPIOYMENT & 668.9 & 817.8 & 836.0 & -18.2 & 97.8 & & & \\
\hline TOTAL MANUFACTURING PAYROLL EMPLOYMENT & 192.7 & 178.0 & 210.5 & -32.5 & 84.6 & $-178.57 \%$ & 28.7 & 21.8 \\
\hline TOTAL NONMANUFACTURING PAYROLE EMPLOYMENT & 476.8 & 639.8 & 625.5 & +14.3 & 102.3 & & 71.3 & 78.2 \\
\hline Mining & .3 & .3 & .3 & - & 100.0 & & - & - \\
\hline Contract Consfruction & 40.1 & 44.7 & 46.3 & -1.6 & 96.5 & -8.79 & 6,0 & 5.5 \\
\hline Transportation and Public Utilities & 53.0 & 54.0 & 60.3 & -6.3 & 89.6 & -34.62 & 7.9 & 6.6 \\
\hline Wholesale and Retoil Trade & 138.9 & 183.9 & 179.2 & $+\quad 4.7$ & 102.6 & +25.82 & 20.8 & 22.5 \\
\hline Finance, Insurance and Real Estate & 35.1 & 45.1 & 46.6 & $=1.5$ & 96.8 & -8.24 & 5.2 & 5.5 \\
\hline Services & 98.7 & 145,4 & 138.6 & +6.8 & 104.9 & +37.36 & 14.7 & 17.8 \\
\hline Government & 111.3 & 166.4 & 154.2 & +12.2 & 107.9 & +67.03 & 16.6 & 20.3 \\
\hline \multicolumn{9}{|c|}{ BOSTON } \\
\hline TOTAL NONAGRICULTURAL PAYROLL EMPLOYMENT & 1106.0 & 1281.0 & 1395.3 & -114.3 & 91.8 & & & \\
\hline TOTAL MANUFACTURING PAYROLL EMPLOYMENT & 275.5 & 254.8 & 301.9 & -47.1 & 84.4 & $-41.21 \%$ & 24.9 & 19.9 \\
\hline TOFAL NONMANUFACTURING PAYROLL EMPLOYMENT & 830.4 & 1026.2 & 1093.4 & -67.2 & 93.9 & & 75.1 & 80.1 \\
\hline Contract Construction & 50.2 & 53.8 & 57.9 & -4.1 & 92.9 & …... 3.59 & 4.5 & 4.2 \\
\hline Transportation and Public Utilities & 65.9 & 74.9 & 75.0 & -0.1 & 99.9 & .09 & 6.0 & 5.8 \\
\hline Wholesale and Retail Trade & 249.1 & 301.1 & 321.3 & -20.2 & 93.7 & -17.67 & 22.5 & 23.5 \\
\hline Finance, fnsurance and Real Estafe & 77.6 & 93.9 & 103.1 & -9.2 & 91.1 & - 8.05 & 7.0 & 7.3 \\
\hline Services and Mining ${ }^{* *}$ & 233.8 & 325.3 & 323.7 & +2.2 & 100.7 & $+\quad 1.92$ & 21.7 & 25.4 \\
\hline Government & 153.8 & 177.2 & 213.0 & -35.8 & 83.2 & -31.32 & 13.9 & 13.8 \\
\hline \multicolumn{9}{|c|}{ CLEYELAND } \\
\hline TOTAL NONAGRICUITURAL PAYROLL EMPLOYMENT & 735.4 & 839.5 & 904.1 & -64.6 & 92.9 & & & \\
\hline TOTAL MANUFACTURING PAYROLL EMPLOYMENT & 283.9 & 272.3 & 311.2 & -38.9 & 87.5 & $-60.12 \%$ & 38.6 & 32.4 \\
\hline FOTAL NONMANUFACTURING PAYROLL EMPLOYMENT & 451.6 & 567.1 & 592.9 & -25.8 & 95.6 & & 61.4 & 67.6 \\
\hline Mining & 1.3 & 1.5 & 1.2 & +0.3 & 125.0 & $+\quad 46$ & 0.2 & 0.2 \\
\hline Confract Construction & 31.1 & 29.1 & 35.9 & -6.8 & 81.1 & -10.51 & 4.2 & 3.5 \\
\hline Transportation and Public Utilities & 46.0 & 49.2 & 52.3 & -3.1 & 94.1 & $-\quad 4.79$ & 6.3 & 5.9 \\
\hline Wholesale and Retail Trade & 148.7 & 185.8 & 191.8 & 6.0 & 96.9 & 9.27 & 20.2 & 22.1 \\
\hline Finance, Insurance and Real Estate & 35.2 & 42.5 & 46.7 & 4.2 & 91.0 & 6.49 & 4.8 & 5.1 \\
\hline Services & 102.0 & 143.2 & 344.1 & 0.9 & 99.4 & 1.39 & 13.9 & 17.1 \\
\hline Government & 87.3 & 115.8 & 120.9 & -5.1 & 95.8 & -7.88 & 11.9 & 13.8 \\
\hline
\end{tabular}




\begin{tabular}{|c|c|c|c|c|c|c|c|c|c|}
\hline \multicolumn{10}{|c|}{ DETROIT } \\
\hline TOTAL NONAGRICULTURAL PAYROLL EMPLOYMENT & 1277.0 & 1477,0 & 1563.3 & 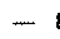 & 86.3 & 94.5 & & & \\
\hline TOTAL MANUFACTURING PAYROLL EMPLÒYMENT & 535.8 & 535.2 & 587.2 & -5 & 52.0 & 91.1 & $=60.32 \%$ & $\$ 2.0$ & 36.2 \\
\hline TOTAL NONMANUFACTURING PAYROLL EMPLOYMENT & 741.3 & 941.9 & 976.1 & -3 & 34,2 & 96.5 & & 58.1 & 63.8 \\
\hline Mining & 0.9 & 0.7 & 0.9 & - & 0.2 & 77.8 & .23 & 0.1 & - \\
\hline Contract Construction & 51.3 & 56.2 & 59.2 & - & 3.0 & 94.9 & 3.48 & 4.0 & 3.8 \\
\hline Transportation and Public Utilities & 67.1 & 77.9 & 76.4 & + & 1.5 & 102.0 & +1.74 & 5.3 & 5.3 \\
\hline Whofesale and Retail Trade & 247.0 & 296.1 & 318.6 & $-i$ & 22.5 & 92.9 & -26.10 & 19.3 & 20.0 \\
\hline Finance, Insurance and Real Estate & 54.7 & 70.1 & 72.6 & - & 2.5 & 96.6 & -2.90 & 4.3 & 4.7 \\
\hline Services & 170.0 & 227.7 & 240.2 & - & $\$ 2.5$ & 94,8 & -14.50 & 13.3 & 15.4 \\
\hline Government & 150.3 & 213.2 & 208.2 & + & 5.0 & 102.4 & +5.80 & 11.8 & 14.4 \\
\hline \multicolumn{10}{|c|}{ PITTSBURGH } \\
\hline TOTAL NONAGRICUITURAL PAYROLLL EMPLOYMENT & 768.5 & 860.7 & 945.6 & $-\varepsilon(\gamma-\gamma)$ & 84.9 & 91.0 & & & \\
\hline TOTAL MANUFACTURING PAYROLL EMPLOYMENT & 278.1 & 256.6 & 304.8 & -2 & 48.2 & 84.2 & $-56.91 \%$ & 36.2 & 29.8 \\
\hline TOTAL NONMANUFACTURING PAYROLL EMPLOYMENT & 490.4 & 604.3 & 640.8 & -3 & 36.5 & 94.3 & & 63.8 & 70.2 \\
\hline Mining & 9.5 & 10.5 & 9.1 & + & 1.4 & 115,4 & +1.65 & 1.2 & 1.2 \\
\hline Contract Construction & 34.7 & 40.9 & 40.0 & + & 0.9 & 102.3 & +1.06 & 4.5 & 4.8 \\
\hline Transportation and Public Utilifies & 54.9 & 58.0 & 62.5 & - & 4.5 & 92.8 & -5.31 & 7.1 & 6.7 \\
\hline Wholesale and Retail Trade & 151.0 & 179.8 & 194.8 & & 15.0 & 92.3 & -17.71 & 19.6 & 20.9 \\
\hline Fincince, Insurance and Real Estate & 32.4 & 38.3 & 43.0 & - & 4.7 & 89.1 & -5.55 & 4.2 & 4.4 \\
\hline Services & 124.2 & 16.2 .6 & 175.5 & -1 & 12.9 & 92.6 & -15.23 & 16.2 & 18.9 \\
\hline Government & 83.7 & 114.2 & 115.9 & - & 1.7 & 98.5 & -2.01 & 10.9 & 13.3 \\
\hline \multicolumn{10}{|c|}{ ST. LOUIS } \\
\hline TOTAL NONAGRICUITURAL PAYROLE EMPLOYMENT & 783.0 & 881.1 & 966.6 & & 85.5 & 91.2 & & & \\
\hline TOTAL MANUFACTURING PAYROLL EMPLOYMENT & 268.6 & 256.7 & 294.4 & -2 & 37.7 & 87.2 & $-44.09 \%$ & 34.3 & 29.1 \\
\hline TOTAL NONMANUFACTURING PAYROLL EMPLOYMENT & 574.4 & 624.4 & 672.2 & - & 47.8 & 92.9 & & 65.7 & 70.9 \\
\hline Mining & 2.8 & 2.7 & 2.7 & & - & 100.0 & $\ldots$ & 0.4 & 0.3 \\
\hline Contract Construction & 40.1 & 32.0 & 46.3 & & 14.3 & 69.1 & -16.73 & 5.1 & 3.6 \\
\hline Transportation and Public Utilities & 63.3 & 63.8 & 72.0 & - & 8.2 & 88.6 & $=9.59$ & 8.1 & 7.2 \\
\hline Wholesale and Refail Trade & 160.0 & 192,4 & 206.4 & & 14.0 & 93.2 & -16.37 & 20.4 & 21.8 \\
\hline Finance, Insurance and Real Estate & 40.5 & 46.7 & 53.8 & - & 7.1 & 86.8 & -8.30 & 5.2 & 5.3 \\
\hline Servites & 116.9 & 156.4 & 165.2 & - & 8.8 & 94.7 & $-=10.29$ & 14.9 & 17.8 \\
\hline Government & 90.8 & 130.4 & 125.8 & + & 4.6 & 103.7 & +5.38 & 11.6 & 14.8 \\
\hline \multicolumn{10}{|c|}{ SAN FRANCISCO } \\
\hline TOTAL NONAGRICULTURAL PAYROLL EMPLOYMENT & 1049.4 & 1258.5 & 1333.9 & & 75.4 & 94.3 & & & \\
\hline TOTAL MANUFACTURING PAYROLL EMPLOYMENT & 195.3 & 186.8 & 214.0 & -2 & 27.2 & 87.3 & $-36.07 \%$ & 18.6 & 14.8 \\
\hline TOTAL NONMANUFACTURING PAYROLL EMPLOYMENT & 854.1 & 1071.7 & 1119.9 & - & 48.2 & 95.7 & & 81.4 & 85.2 \\
\hline Mining & 1.9 & 1.8 & 1.8 & & - & 100.0 & - & 0.2 & 0,1 \\
\hline Contract Construction & 64.1 & 59.2 & 74.0 & & 14.8 & 80.0 & -19.63 & 6.1 & 4.7 \\
\hline Transportation and Public Utilities & 103.2 & 126.5 & 117.4 & + & 9.1 & 107.8 & +12.07 & 9.8 & 10.1 \\
\hline Wholesole and Retail Trade & 231.1 & 273.4 & 298.1 & -2 & 24.7 & 91.7 & -32.76 & 22.0 & 21.7 \\
\hline Fingance, Insurance and Real Estate & 79.6 & 104.2 & 105.7 & - & 9.5 & 98.6 & $-\quad 1.99$ & 7.6 & 8.3 \\
\hline Services & 164.6 & 233.1 & 232.6 & + & 0.5 & 100.2 & +.66 & 5.7 & 18.5 \\
\hline Government & 209.6 & 273.5 & 290.3 & -1 & 16.8 & 94.2 & -22.28 & 20.0 & 21.7 \\
\hline \multicolumn{10}{|c|}{$\begin{array}{l}\text { "Prajected payroll employment in each industrial sector for } 1972 \text { equals what payroll employment would have been if it had grown at the national rate for that seetor between } 1964 \text { a } \\
\text { 1972. Projected employment for aggregate sectors is the sum of that for their component seetors. }\end{array}$} \\
\hline
\end{tabular}

